\title{
THE IMPACT OF ALDINGER V. HOWARD ON PENDENT PARTY JURISDIGTION
}

The Supreme Court has recently reexamined pendent party jurisdiction in Aldinger \%. Howard. ${ }^{1}$ Monica Aldinger, a clerical worker, was fired by Merton Howard, county treasurer of Spokane County, Washington. She was told that the firing was due to her living with her boyfriend. Her pursuit of legal redress for the dismissal resulted in a decision casting some doubt on the power of federal courts to hear "pendent party" claims in general and rejecting altogether such jurisdiction in suits brought under 42 U.S.C. section $1983 .^{2}$

Plaintiff alleged that defendants Howard, the county, and the County Commissioners violated her substantive ${ }^{3}$ and procedural $^{4}$ federal constitutional rights. Suing under section 1983, she sought both damages for her lost salary and an injunction ordering her reinstatement. The county was alleged to be vicariously liable ${ }^{5}$ for the acts of treasurer Howard and was joined as a defendant under section 1983 and as a "pendent party." Plaintiff asserted that pendent jurisdiction, which allows a federal court to join a claim lacking independent subject matter jurisdiction to a claim conferring federal jurisdiction, ${ }^{6}$ could be extended to reach parties who were not defendants to the federal claims. The district court's dismissal of the county as defendant ${ }^{7}$ was af-

196 S. Ct. 2413 (1976).

242 U.S.C. $§ 1983$ (1970) reads:

Every person who, under color of any statute, ordinance, regulation, custom, or usage, of any State or Territory, subjects, or causes to be subjected, any citizen of the United States or other person within the jurisdiction thereof to the deprivation of any rights, privileges, or immunities secured by the Constitution and laws, shall be liable to the party injured in an action at law, suit in equity, or other proper proceeding for redress.

3 The Second Amended Complaint sought relief under the first, ninth, and fourteenth amendments. Appendix at 15-16, Aldinger v. Howard, 96 S. Ct. 2413 (1976). The merit of Aldinger's claim was not before the Court nor is it the subject of this Comment.

${ }^{4} \mathrm{~A}$ hearing was requested by Aldinger, but allegedly none was held either before or after her dismissal. $96 \mathrm{~S}$. Ct. at 2415.

${ }^{5}$ See WASH. REV. CODE $\$ 4.08 .120$ (1974) (authorizing actions in tort or contract against county); id. $\$ 4.96 .010$ (holding political subdivisiors liable for torts of employees).

${ }^{6}$ See text accompanying note 21 infra.

${ }^{7}$ Appendix, supra note 3 , at 20-21. 
firmed by the Court of Appeals for the Ninth Circuit. ${ }^{8}$ The court followed the established rule that local government entities ${ }^{9}$ were not liable under section $1983^{10}$ and also dismissed plaintiff's state law claim premised on respondeat superior for want of subject matter jurisdiction. Although "not unaware of the widespread rejection"11 of its approach by the other circuits, the court reaffirmed its view that jurisdiction does not exist over a "pendent party" not subject to a federal jurisdiction-conferring claim. ${ }^{12}$

The Supreme Court, limiting certiorari to the question of pendent jurisdiction over the county, affirmed. It believed that jurisdiction over a pendent party should be determined by looking to the "scope" of the cause of action enabling entry into federal court. ${ }^{13}$ Because the Court had previously held that Congress did not intend that municipalities incur liability under section 1983, it concluded that allowing a federal court to hear pendent state law claims of vicarious liability against the county would "circumvent" the municipality exclusion carved out by Congress. ${ }^{14}$

This Comment explores the reasoning and reach of Aldinger. Basing its holding on an approach to pendent party jurisdiction neither argued in the briefs nor raised in the literature on the subject, ${ }^{15}$ the Court's interpretation overlooks a number of

${ }^{8}$ Aldinger v. Howard, 513 F.2d 1257 (9th Cir. 1975), aff'd, 96 S. Ct. 2413 (1976).

${ }^{9}$ The terms city, county, municipality, and local government are used interchangeably in this Comment.

${ }^{10} 513$ F.2d at 1259. This issue was settled by Monroe v. Pape, 365 U.S. 167 (1961) (city not liable for damages under $\$ 1983$ ) and City of Kenosha v. Bruno, 412 U.S. 507 (1973) (local government entities not liable in equity under $\$ 1983$ ). In Moor v. County of Alameda, 411 U.S. 693 (1973), the Court held municipalities not liable under $\$ 1983$ even if the state had waived municipal immunity from tort liability, and upheld discretionary dismissal of the pendent party claim against the county. See note 81 infra.

${ }^{11} 5 \mathrm{l} 3 \mathrm{~F} .2 \mathrm{~d}$ at 1261 . See note 23 infra.

${ }^{12}$ See Hymer v. Chai, 407 F.2d 136 (9th Cir. 1969).

${ }^{13}$ Aldinger v. Howard, $96 \mathrm{~S}$. Ct. 2413, 2421 (1976). The narrow issue in Aldinger - the power to join nonfederal parties to $\S 1983$ suits-had received a mixed reaction in the circuit and district courts. Compare Almenares v. Wyman, 453 F.2d 1075 (2d Cir. 1971), cert. denied, 405 U.S. 944 (1972); Redding v. Medica, 402 F. Supp. 1260 (W.D. Pa. 1975) (pendent defendant allowed); Stamm v. Trigg, 368 F. Supp. 83 (N.D. Ohio 1973) (pendent defendant allowed); Eidshun v. Pierce, 335 F. Supp. 603 (S.D. Iowa 1971) (allowing pendent action) with, e.g., Hymer v. Chai, 407 F.2d 136 (9th Cir. 1969); Greenway v. Thompson, 368 F. Supp. 387 (N.D. Ga. 1973) (dismissing pendent municipality on ground that it enjoys municipal tort immunity); Anthony v. Cleveland, 355 F. Supp. 789 (D. Hawaii 1973) (disallowing pendent party defendant under Ninth Circuit rule); Fire v. City of Winner, 352 F. Supp. 925 (D.S.D. 1972) (discretionary dismissal of tort claim pendent to $\$ 1983$ claim).

1496 S. Ct. at 2421.

${ }^{15}$ E.g., Fortune, Pendent Jurisdiction-the Problem of "Pendenting Parties", 34 U. PITT. 
historical and logical problems that indicate difficulties with the approach itself. Although Aldinger now governs pendent party jurisdiction in section 1983 cases, it should be limited to that context.

United Mine Workers v. Gibbs, ${ }^{16}$ the seminal pendent party jurisdiction case from which Aldinger departs, should be used in other contexts to determine the appropriateness of asserting federal jurisdiction over nonfederal claims and parties.

\section{The Case for Pendent Party Jurisdiction}

Aldinger relied principally on two prudential arguments, based on the law of res judicata ${ }^{17}$ and of ancillary jurisdiction, ${ }^{18}$ favoring pendent party jurisdiction. These considerations, as well as those recognized in Gibbs, ${ }^{19}$ favor the "pendenting" of the municipal defendant despite the lack of independent federal subject matter jurisdiction.

\section{A. The Influence of Gibbs}

That state law claims against a party may be heard in federal court as pendent to a federal claim against the same defendant has long been settled. Joining a claim against one defendant that is beyond the reach of federal subject matter jurisdiction to a factually-related federal suit against another defendant did not seem feasible, however, until Gibbs propounded the modern rule of pendent jurisdiction:

Pendent jurisdiction, in the sense of judicial power, exists whenever there is a claim "arising under [the] Constitution, the Laws of the United States, and Treaties made, or which shall be made, under their Authority ..."

L. Rev. I (1972); Shakman, The New Pendent Jurisdiction of the Federal Courts, 20 STAN. L. Rev. 262 (1968); Comment, Federal Pendent Subject Matter Jurisdiction-the Doctrine of United Mine Workers v. Gibbs Extended to Persons Not Party to the Jurisdiction-Conferring Claims, 73 Colum. L. Rev. 153 (1973) [hereinafter cited as Columbia Note]; Note, UMW v. Gibbs and Pendent Jurisdiction, 81 Harv. L. Rev. 657 (1968); Comment, Pendent and Ancillan Jurisdiction: Towards a Synthesis of Two Doctrines, 22 U.C.L.A. L. Rev. 1263 (1975) [hereinafter cited as Synthesis]; Note, Federal Pendent Party Jurisdiction and United Mine Workers v. Gibbs-Federal Question and Diversity Cases, 62 VA. L. REv. 194 (1976) [hereinafter cited as Virginia Note]; 4 U. ToL. L. REv. 201 (1973).

${ }^{16} 383$ U.S. 715 (1966).

${ }^{17}$ See generally Fortune, supra note 15, at 8-9; McCormack, Federalism and Section 1983: Limitations on Judicial Enforcement of Constitutional Protections (Parts I \& II), 60 VA. L. Rev. 1, 250 (1974); Columbia Comment, supra note 15, at 166; Virginia Note, supra note 15 , at 209-14.

${ }^{18}$ See generally Synthesis, supra note 15.

${ }^{19}$ See text accompanying notes $26-28$ infra. 
U.S. Const., Art. III, $\S 2$, and the relationship between that claim and the state claim permits the conclusion that the entire action before the court comprises but one constitutional "case." The federal claim must have substance sufficient to confer subject matter jurisdiction on the court. ... The state and federal claims must derive from a common nucleus of operative fact. But if, considered without regard to their federal or state character, a plaintiff's claims are such that he would ordinarily be expected to try them all in one judicial proceeding, then, assuming substantiality of the federal issues, there is power in federal courts to hear the whole.

That power need not be exercised in every case in which it is found to exist. It has consistently been recognized that pendent jurisdiction is a doctrine of discretion, not of plaintiff's right. Its justification lies in considerations of judicial economy, convenience and fairness to litigants; if these are not present a federal court should hesitate to exercise jurisdiction over state claims, even though bound to apply state law to them. ${ }^{20}$

Gibbs thus created a two-part test for the "pendenting" of claims not otherwise within federal jurisdiction: power exists when the state and federal claims arise from the same "operative facts," and discretion is appropriate when prompted by considerations of economy, convenience, and fairness.

Gibbs, however, involved a pendent claim rather than a pendent party. ${ }^{21}$ The lower courts have been left to apply the rationale of Gibbs to the "pendenting" of parties. Six circuits have relied on Gibbs to find federal court jurisdiction over pendent parties, ${ }^{22}$ while only the Ninth and the Seventh Circuits have

211 383 U.S. at 725-26 (footnotes omitted).

21 There is dictum in Gibbs to augment the case for pendent parties. In arguing for a more generous application of pendent jurisdiction in general, the Court took note that under the Federal Rules of Civil Procedure, "joinder of . . parties . . . is strongly encouraged." Id. at 724. The reference is presumably to rules 14 and 20 , FED. R. Crv. P. $14 \& 20$, and to the doctrine of ancillary jurisdiction, see text accompanying notes 49-58 infra. Of course the rules themselves cannot overstep the constitutional limitations of federal jurisdiction.

${ }^{22}$ Second Circuit: Almenares v. Wyman, 453 F.2d 1075 (2d Cir. 1971), cert. denied, 405 U.S. 944 (1972) (class action failing to meet amount in controversy pendent to $\S 1983$ suit); Leather's Best, Inc. v. S.S. Mormaclynx, 451 F.2d 800 (2d Cir. 1971) (state tort claim pendent to federal suit in admiralty); Astor-Honor Inc. v. Grosset \& Dunlap, Inc., 441 F.2d 627 (2d Cir. 1971) (state unfair competition claim pendent to federal copyright claim). 
adhered to their pre-Gibbs positions ${ }^{23}$ that pendent jurisdiction would not reach parties not defendant to the jurisdictionconferring claim. ${ }^{24}$

Those courts and commentators who favor pendent party jurisdiction look to the same principles of economy, convenience, and fairness animating Gibbs. ${ }^{25}$ In allowing the "pendenting" of a state claim, Gibbs acknowledged such considerations as the fear of inconsistent adjudication or prejudicial application of res judicata if claims are raised separately, ${ }^{26}$ the need to adjudicate federal questions and state law issues implicating federal policy in federal court, ${ }^{27}$ the liberal joinder philosophy of the federal

Third Circuit: Curtis v. Everette, 489 F.2d 516 (3d Cir. 1973), cert. denied, 416 U.S. 995 (1974) (state tort claim pendent to federal civil rights claim); Jacobson v. Atlantic City Hosp., 392 F.2d 149 (3d Cir. 1968) (pendent party defendant in diversity suit when amount in controversy not sufficient as to that pary); Wilson v. American Chain \& Cable Co., 364 F.2d 558 (3d Cir. 1966) (pendent party plaintiff, parent suing for consequential damages in child's federal tort suit).

Fourth Circuit: Stone v. Stone, 405 F.2d 94 (4th Cir. 1968) (pendent party defendant in diversity suit).

Fifth Circuit: Florida E.C.R.R. v. United States, 519 F.2d 1184 (5th Cir. 1975) (state tort claim pendent to Federal Tort Claims Act claim); Connecticut Gen. Life Ins. Co. v. Craton, 405 F.2d 41 (5th Cir. 1968) (pendent party defendant in federal labor relations suit).

Sixth Circuit: Beautytuft, Inc. v. Factory Ins. Ass'n, 431 F.2d 1122 (6th Cir. 1970) (pendent party defendant in diversity suit); F.C. Stiles Contracting Co. v. Home Ins. Co., 431 F.2d 917 (6th Cir. 1970) (same). See Patrum v. City of Greensburg, 419 F.2d 1300 (6th Cir. 1969), cert. denied, 397 U.S. 990 (1970) (affirming discretionary refusal to join municipality as pendent defendant in $\$ 1983$ suit against police).

Eighth Circuit: Schulman v. Huck Finn, Inc., 472 F.2d 864 (8th Cir. 1973) (copyright and pendent unfair competition claims); Hatridge v. Aetna Cas. \& Sur. Co., 415 F.2d 809 (8th Cir. 1969) (wife's claim for loss of consortium pendent to husband's diversity suit).

The First and Tenth Circuits have not had the opportunity to consider pendent party jurisdiction.

${ }^{23}$ See Wojtas v. Village of Niles, 334 F.2d 797 (7th Cir. 1964); Kataoka v. May Dep't Stores Co., 115 F.2d 521 (9th Cir. 1940).

${ }^{24}$ Seventh Circuit: Hampton v. City of Chicago, 484 F.2d 602 (7th Cir. 1973), cert. denied, 415 U.S. 917 (1974) (diversity suit). Ninth Circuit: Aldinger v. Howard, 513 F.2d 1257 (9th Cir. 1975), aff'd, 96 S. Ct. 2413 (1976); Moor v. Madigan, 458 F.2d 1217 (9th Cir. 1972) (no cognizable federal claim under Civil Rights Act, therefore pendent state claim should be dismissed), aff'd in part sub nom. Moor v. County of Alameda, 411 U.S. 693 (1973); Hymer v. Chai, 407 F.2d 136 (9th Cir. 1969) (wife's claim for loss of consortium not pendent to husband's diversity suit). Because these cases rely on pre-Gibbs holdings, supra note 24, they are "suspect as authority." 3A MOORE's FEDERAL PRAcTice If 18.07[1.-4], at 1953 (2d ed. 1948).

${ }^{25}$ E.g., Curtis v. Everette, 489 F.2d 516, 520 (3d Cir. 1973), cert. denied, 416 U.S. 995 (1974); Leather's Best, Inc. v. S.S. Mormaclynx, 451 F.2d 800, 811 (2d Cir. 1971).

${ }^{26}$ E.g., Fortune, supra note 15, at 7-9. See text accompanying notes 34-48 infra.

${ }^{27}$ E.g., Almenares v. Wyman, 453 F.2d 1075, 1085 (2d Cir. 1971), cert. denied, 405 U.S. 944 (1972). 
rules of civil procedure, ${ }^{28}$ the principle of avoidance of constitutional questions, ${ }^{29}$ and the similarity of pendent party to ancillary jurisdiction. ${ }^{30}$ These considerations can be applied to determining the propriety of pendenting a party as well as a claim. Indeed, nothing in Gibbs indicates that, as long as the pendent party claim arises from the same "operative facts" as the jurisdiction-conferring claim, the joinder of the pendent party would violate the constitutional requirements for the assertion of federal jurisdiction. A district court may in its discretion join pendent parties without transgressing the jurisdictional limits of the "case or controversy" requirement of article III; the flexibility of article III in not requiring that there never be a nonfederal litigant is evidenced by the allowance of ancillary jurisdiction. ${ }^{31}$

The pendent party question arises under varied configurations of litigants, including proposed additional plaintiffs as well as defendants, who may or may not already be ancillary parties. Pendent party jurisdiction may be asserted in both diversity and federal question suits, and, in the latter case, under a multitude of federal statutes. ${ }^{32}$ The Gibbs two-part test provides standards for ascertaining when courts should use discretion to consider claims involving such various configurations. Aldinger did not recognize this discretion, though. The Court imposed a flat ban on pendent party jurisdiction in section 1983 cases without considering the resultant logical inconsistency and impracticality. $\mathrm{Al}$ dinger leaves a section 1983 plaintiff with three unsatisfactory alternatives: to bring the federal claim only and forego monetary recovery against the municipality; to bring both the federal and state claims in state court and frustrate the policy of federal court adjudication of federal rights; or to bring separate federal and state actions and risk the res judicata effect if the first suit reaching a decision is lost.

${ }^{28}$ See Synthesis, supra note 15 , at 1273.

${ }^{29}$ In AImenares v. Wyman, 453 F.2d 1075 (2d Cir. 1971), cert. denied, 405 U.S. 944 (1972), joinder of the pendent party claim enabled the court to dispose of the case on the basis of statutory interpretation, and thus to avoid the constitutional issues raised by the jurisdiction conferring claim under $\$ 1983$.

${ }^{30}$ Florida E.C.R.R. v. United States, 519 F.2d 1184, 1195 (5th Cir. 1975); Leather's Best, Inc. v. S.S. Mormaclynx, 451 F.2d 800, 809-11 (2d Cir. 1971); Synthesis, supra note 15. See Moor v. County of Alameda, 411 U.S. 693, 714-15 (1973).

${ }^{31}$ See text accompanying notes 49-61 infra.

32 See 13 C. Wright \& A. Miller, Federal Practice \& Procedure § 3567 (1975). Fortune, supra note 15 , at 8 , notes that FELA cases and $\S 1983$ give rise to the majority of pendent party disputes. 


\section{B. Res Judicata and the Need for a Federal Forum}

The consequence of denying pendent party jurisdiction is that plaintiff's state claims must be raised in state court, leaving the federal questions for determination in a separate federal forum. ${ }^{33}$ This prospect of split litigation may influence the plaintiff to bring the entire matter into the state tribunal to avoid the delay, expense, and possible contradictory holdings of the split suit. ${ }^{34}$ Such an inhibiting effect on federal actions sacrifices the authoritative adjudication of federal questions in federal court, ${ }^{35}$ which is especially needed when the civil rights claim under section 1983 charges unconstitutional action under the aegis of the state $^{36}$ and justifiable because the purpose of section 1983 was to open the federal courts to those claims thought to be unrelieved by some state courts. ${ }^{37}$

${ }^{33}$ In cases where the agent is adequately bonded against tort suits, the need to reach his employer is diminished. A personal judgment against him in federal court will facilitate recovery on the bond in state court. Otherwise, the municipal employer will have to be sued in state court on the respondeat superior issue. See $3 \mathrm{~K}$. Davis, AdMinistrative Law TREatise $\$ 25.04$ (1958).

${ }^{34}$ Section 1983 is open to concurrent federal and state court jurisdiction. Long v. District of Columbia, 469 F.2d 927, 937 (D.C. Cir. 1972).

${ }^{35}[\mathrm{~T}]$ he state courts may actually be less qualified to render decisions based on the United States Constitution. The concept of state sovereignty fosters a parochial outlook on individual claims of constitutional dimension. State courts will often be most interested in questions of state law and in adapting constitutional principles to local conditions rather than in fleshing out rules of general application. The fact that many state judges are elected officials bolsters this localized concern. Moreover, the state courts have no obligation to consider the extra-territorial impact of their decisions, and although the highest court of a state may be well aware that its judgments are subject to review by the Supreme Court, it will feel little compulsion to accept the rules of decision laid down by the courts of appeals or the precedents of the federal district courts sitting in its state.

McCormack, supra note 17, at 263-64 (footnotes omitted). See AMERICAN LAw INSTItute, The Division of Jurisdiction Between State and Federal Courts I64-68 (1969).

${ }^{36}$ Petitioner Aldinger likewise argued the awkwardness of having to bring part or all of her action in the state court, "in the very same building in which the acts that gave rise to the violation occurred, and ask one agency of Spokane County, the court, to assess damages against both the County and the employee of another county agency." Brief for Petitioner at 59, Aldinger v. Howard, 96 S. Ct. 2413 (1976).

${ }^{37} \mathrm{Mr}$. Justice Brennan, dissenting in Aldinger, is clearly correct in his assertion, 96 S. Ct. at $2427-30$, that the $42 \mathrm{~d}$ Congress intended to open the federal courts to redress civil rights violations by the states because of the failure of some state courts to enforce such protections effectively. The following passages from the 1871 debates are illustrative:

The United States courts are further above mere local influence than the county courts; their judges can act with more independence, cannot be put under terror, as local judges can; their sympathies are not so clearly identified with those of the vicinage; the jurors are taken from the State, and not the 
The alternative of splitting the civil rights claim-a section 1983 action against the individual wrongdoer, and a state court suit of vicarious or independent liability against the municipal employer-is still possible after Aldinger. Yet splitting the federal and state claims will preserve the underlying issue of liability for infringement of constitutional rights for federal court only if the state litigation does not preclude federal adjudication of the same facts. If plaintiff loses the first action to reach judgment, he will be barred from relitigating liability in the parallel suit. ${ }^{38}$ If the state litigation reaches judgment first, ${ }^{39}$ the rule that prior state proceedings will not operate as res judicata on a subsequent section 1983 action if the constitutional issues were not heard in state court, even if recognized, ${ }^{40}$ will not avail a plaintiff whose state claim was premised on vicarious liability and necessarily

neighborhood; they will be able to rise above prejudices or bad passions or terror more easily.

CoNG. GloBe, 42d Cong., 1st Sess. 460 (1871) (remarks of Rep. Coburn). "[R]ecords of the [state] tribunals are searched in vain for any evidence of effective redress. . . . Hence this bill throws open the doors of the United States courts to those whose rights under the Constitution are denied or impaired." Id. 374-76 (remarks of Rep. Lowe). See, e.g., id. 321 (Rep. Stoughton); id. 333-34 (Rep. Hoar); id. 389 (Rep. Elliot); id. 394 (Rep. Rainey); id. 429 (Rep. Beatty); id. 345 (Sen. Sherman); id. 505 (Sen. Pratt); id 577 (Sen. Carpenter); id. 651 (Sen. Sumner); id. 653 (Sen. Osborn).

See Mitchum v. Foster, 407 U.S. 225, 238-42 (1972); Monroe v. Pape, 365 U.S. 167, 180 (1961) ("It is abundantly clear that one reason the legislation [ 81983 ] was passed was to afford a federal right in federal courts because, by reason of prejudice, passion, neglect, intolerance or otherwise, state laws might not be enforced . . . ."); Ex parte Virginia, 100 U.S. 339, 346 (1879) ( $\$ 1983$ intended to enforce 14th Amendment "against State action ... whether that action be executive, legislative, or judicial"); $P$. Bator, P. Mishkin, D. Shapiro \& H. Wechsler, Hart \& Wechsler's The Federal Courts and the Federal System 922-23 (2d ed. 1973); Fortune, supra note 15, at 8.

The parochialism and prejudice of state courts of the 1870's may have abated, but the issue remains vital as a result of the Court's singleminded focus on the congressional intent in enacting $\S 1983$. If the Court's approach requires indifference to the apparent dissipation of the original reasons for the municipality exclusion, see note 92 infra and accompanying text, it would hardly be consistent for it to emphasize modern policy factors diminishing the need for a federal forum to litigate civil rights claims.

${ }^{38}$ See Virginia Note, supra note 15, at 209-10 discussing the special problems faced by $\S 1983$ plaintiffs because of the "no mutuality" trend in the law of res judicata. Petitioner Aldinger claimed resultant prejudice. Brief for Petitioner at 51 \& $\mathrm{n} .15$, Aldinger v. Howard, 96 S. Ct. 2413 (1976).

39 Note the short statute of limitations on the action against the county in Aldinger. WASH. REv. CODE \$ 36.45.010 (1974) (120 days). For discussion of the possible role of federal court abstention in such a case, see McCormack, supra note 17, at 293.

40 See Newman v. Board of Educ., 508 F.2d 277 (2d Cir.), cert. denied, 420 U.S. 1004 (1975); Lombard v. Board of Educ., 502 F.2d 631 (2d Cir. 1974), cert. denied, 420 U.S. 976 (1975); McCormack, supra note 17, at 250, 291. But see, e.g., Frazier v. East Baton Rouge Parish School Bd., 363 F.2d 861 (5th Cir. 1966) (prior state adjudication is conclusive on all issues that might have been raised respecting plaintiff's claim of wrongful dismissal of employment, even though constitutional issues were not raised until later $\S 1983$ suit at bar). 
litigated the constitutional violations of the municipal employee. ${ }^{41}$ Even if plaintiff wins his federal suit against the individual tortfeasor, the municipality may relitigate both its own and the underlying liability of its servant, unless it actively participated in the federal litigation against the individual defendant. ${ }^{42}$

Two points are illustrated by these possible applications of res judicata to the split civil rights suit. First, although Aldinger on its face does not deny a federal forum for the individualliability suit within the scope of section 1983, familiar and facially neutral rules of preclusion may in effect deny the plaintiff a federal forum for any matter litigated in state court and binding on the federal action. Second, the principles of fairness and judicial economy that underlie res judicata ${ }^{43}$ are similar to those justifying pendent jurisdiction. ${ }^{44}$ The justifications for a single adjudication are especially strong when the state claim is respondeat superior and the case to be proven corresponds closely to the federal case of personal liability. ${ }^{45}$ Relitigating the facts when the claims are so similar would contravene the policy noted in Monroe $\%$. Pape, ${ }^{46}$ that "[t]he federal remedy [section 1983] is supplementary to the state remedy, and the latter need not be first sought and refused before the federal one is invoked."47

\section{The Analogy to Ancillary Jurisdiction}

The doctrine of ancillary jurisdiction allows parties to claims lacking independent federal subject matter jurisdiction-such as

41 Independent suits litigating the same liability raise the possibility of inconsistent adjudications and of mulcting the defendants for excess damages if plaintiff succeeds in both federal and state court. See Sea-Land Servs., Inc. v. Gaudet, 414 U.S. 573, 612-13 (1974) (Powell, J., dissenting). The potential for inconsistent adjudications is especially troublesome where the pendent claim under state law supplements and effectuates federal law. E.g., Sherrod v. Pink Hat Cafe, 250 F. Supp. 516 (N.D. Miss. 1965) (state assault claim pendent to $\$ 1983$ claim against same defendant). See text accompanying notes $96-97$ infra.

42 Restatement of Judgments $\$ \$ 96,99$ (1942); W. Seavey, Handbook of the LAw of AGENCY $\S 95$ (1964). In the most troubling cases, where plaintiff asserts alternative liability against the federal and state defendants, forcing him to split his action opens the possibility that both defendants may successfully assert that the other party was solely liable. The prospect of such inconsistent adjudication is noted in Fortune, supra note 15, at 9. See text accompanying note 101 infra. See also 3A MoOre's Federal PRACTICE I 18.07[1..4], at 1952-53 (2d ed. 1948).

4350 C.J.S. Judgments $\$ 592$ (1947 \& Supp. 1976) (collecting authorities).

${ }^{44}$ See text accompanying note 21 supra.

${ }^{45}$ Kates \& Kouba, Liability of Public Entities Under Section 1983 of the Civil Rights Act, 45 S. CAL. L. REv. 131, 163 (1972).

${ }^{46} 365$ U.S. 167 (1961). See text accompanying note 10 supra.

47365 U.S. at 183. Ironically, Monroe raised the problem by excluding local governments from liability under $\$ 1983$. 
counterclaims ${ }^{48}$ or third party claims ${ }^{49}$ - to become part of a federal suit. ${ }^{50}$ Ancillary power permits federal adjudication of claims ordinarily confined to state courts, provided they arise from the same transaction generating the federal claim. Petitioner Aldinger relied on the similarity of joining parties under pendent and ancillary jurisdiction, and suggested that the novel strategy of joining pendent parties stretches the limits of article III no more than does the well-recognized doctrine of ancillary jurisdiction. ${ }^{51}$

Ancillary jurisdiction, grounded in "fairness" to the parties, ${ }^{52}$ was historically distinguished from pendent jurisdiction, which fostered judicial economy and convenience. ${ }^{53} \mathrm{Gibbs}^{\prime}$ addition of "fairness" to the test for pendent jurisdiction provided a nexus between the two doctrines. ${ }^{54}$ This change was a consequence of Gibbs' redefinition of the scope of pendent jurisdiction. Gibbs rejected the older view that pendent jurisdiction was proper only where the state claim was inherent in the same "cause of action" as the federal claim, ${ }^{55}$ and held that pendent jurisdiction could be asserted when plaintiff's claims arose "from a common nucleus of operative fact. ... such that he would ordinarily be expected to try them all in one judicial proceeding."56 This standard substantially follows the ancillary jurisdiction "same transaction" test expounded in Moore v. New York Cotton Exchange. ${ }^{57}$ In Moore, the Court declared that a federal court had power to decide a compulsory counterclaim although it lacked an independent jurisdictional base.

The Aldinger opinion minimizes the apparent congruity of pendent party and ancillary jurisdiction by suggesting that Moore, not Gibbs, was the "decisional bridge" between ancillary and pendent jurisdiction. ${ }^{58}$ Moore, however, spoke only to the

${ }^{48}$ E.g., United Artists Corp. v. Masterpiece Prods., Inc., 221 F.2d 213 (2d Cir. 1955). See FED. R. CIV. P. 13(a).

${ }^{49}$ E.g., Dery v. Wyer, 265 F.2d 804 (2d Cir. 1959). See FED. R. Civ. P. 14; Synthesis, supra note 15 , at $1282-84$.

${ }^{50}$ For cases dealing with ancillary jurisdiction, see, e.g., Moore v. New York Cotton Exch., 270 U.S. 593, 609-10 (1926); Stewart v. Dunham, 115 U.S. 61 (1885).

51 Brief for Petitioner at 8-18, Aldinger v. Howard, 96 S. Ct. 2413 (1976). See Astor-Honor Inc. v. Grosset \& Dunlap, Inc., 441 F.2d 627, 630 (2d Cir. 1971); Fortune, supra note 15, at 13; Synthesis, supra note 15, at 1264-74. But see Virginia Note, supra note 15, at 194 n.2, 212-13; Shakman, supra note 15.

${ }^{52}$ See Walmac Co. v. Isaacs, 220 F.2d 108 (1st Cir. 1955).

${ }^{53}$ See Synthesis, supra note 15 , at 1263-74.

${ }^{54}$ Id. 1273-74.

${ }^{55}$ Hurn v. Oursler, 289 U.S. 238 (1933).

${ }^{56} 383$ U.S. 715,725 (1966).

57270 U.S. 593, 609-10 (1926).

$5896 \mathrm{~S}$. Ct. at 2419 . The matter is confounded somewhat by the fact that Moore was 
issue of ancillary jurisdiction over state claims against parties already subject to federal claims. Although the case is considered a seminal decision on ancillary jurisdiction, it did not involve a third party action against an ancillary party, over whom no independent federal jurisdiction would have existed, but rather dealt with a state-law counterclaim between the parties already in federal court. ${ }^{59}$ By relying on Moore instead of on Gibbs and ancillary jurisdiction cases reaching nonfederal parties, the Court failed to consider fully the proposition that pendent and ancillary jurisdiction are co-extensive. ${ }^{60}$

\section{The Court's Reliance on "Implications" from THE SCOPE OF SECTION 1983}

Aldinger rejected the foregoing arguments favoring pendent party jurisdiction on the basis of a fundamentally different approach than Gibbs had taken. Instead of deciding whether the state and federal claims arose from the same operative facts, ${ }^{61}$ the Court was concerned solely with Congress' definition of the scope of federal subject-matter jurisdiction as additionally de-

relied on by the Court in Hurn, which also propounded the narrow "same cause of action" test of pendent jurisdiction disapproved in Gibbs.

${ }^{59}$ In Florida E.C.R.R. v. United States, 519 F.2d 1184, 1195 (5th Cir. 1975), sustaining pendent party jurisdiction of a claim against a non-federal party, the court was persuaded in part by the fact that the new defendant was already impleaded under the aegis of ancillary jurisdiction.

${ }^{60}$ Other courts have nevertheless rejected the notion. In perhaps the closest correspondence of ancillary and pendent jurisdiction, where plaintiff asserts pendent state claims against an ancillary third party defendant, federal courts often refuse jurisdiction. E.g., Fawvor v. Texaco, Inc., 546 F.2d 636 (5th Cir. 1977) (analogizing Aldinger); Kenrose Mfg. Co. v. Fred Whitaker Co., 512 F.2d 890 (4th Cir. 1972). See 3A Moore's Federal Practice ff 14.27[1], at 565-74 (2d ed. 1974). This is suggested in Virginia Note, supra note 15, at 213 . Moreover, "pendenting" parties presents a problem of fairness absent in pendent claims against the federal defendant: the pendent party may be subject to personal jurisdiction only because of nationwide service of process authorized by the jurisdiction-conferring claim, or may be brought into an improper venue. These caveats were expressed by Judge Friendly in Astor-Honor Inc. v. Grosset \& Dunlap, Inc., 441 F.2d 627, 629 n.2 (2d Cir. 1971). Compare Cooper v. North Jersey Trust Co., 226 F. Supp. 972, 980-82 (S.D.N.Y. 1964) (pendent claim allowed although defendant made subject to personal jurisdiction by extraterritorial service) with Lasch $\mathrm{v}$. Antkies, 161 F. Supp. 851, 852 (E.D. Pa. 1958) (state claim may not be joined to federal suit when personal jurisdiction of defendant effected by nationwide service). Neither venue nor personal jurisdiction, it appears, would have presented a problem in Aldinger. As to the general applicability of these objections, one might question whether they are properly addressed to the discretion of the district court to deny pendent party jurisdiction because of unfairness, or rather suggest constitutional barriers to the doctrine. Aldinger does not reach these issues. The Court found "little profit in attempting to decide, for example, whether there are any 'principled' differences between pendent and ancillary jurisdiction, or, if there were, what effects Gibbs had on such differences." $96 \mathrm{~S}$. Ct. at 2419.

61 United Mine Workers v. Gibbs, 383 U.S. 715, 725 (1966). 
terminative of the pendent party question. Of primary concern were prior judicial interpretations of the Civil Rights Act of $1871 .^{62}$ In Monroe v. Pape ${ }^{63}$ the Court considered the proposed Sherman Amendment ${ }^{64}$ to that Act which would have imposed liability on a municipality for damage caused by private violence within its borders and discerned a response to it "so antagonistic that we cannot believe that the word 'person' was used in this particular Act to include [municipalities]."65 Monroe decided only a section 1983 suit for damages against the city of Chicago, but City of Kenosha v. Bruno ${ }^{66}$ extended municipal immunity to suits in equity, and Moor v. County' of Alamed ${ }^{67}$ held that the exemption would bar recovery against municipalities even when state law waived municipal tort immunity. ${ }^{68}$

Aldinger's reliance on congressional intent to immunize municipalities, without accepting the dissent's challenge to explore the legislative history, is difficult to justify. Although legislative histories may often yield too much or too little to be of service in construing statutory law, ${ }^{69}$ and, as Mr. Justice Rehnquist observed, the House speeches respecting the 1871 Civil Rights Act are characterized by "diverse strains,"70 discerning the original congressional intent is necessary to determining the appropriate scope of the Aldinger rule. The congressional under-

6242 U.S.C. $\$ 1983$ (1970).

63365 U.S. 167 (1961).

${ }^{64}$ Proposed, Cong. Globe, 42d Cong., 1st Sess. 663 (1871); adopted by Senate, id. 704-05; rejected by House, id. 725; conference committee report, id. 749; House rejects revised Amendment, id. 800-01.

${ }_{65}$ Monroe v. Pape, 365 U.S. 167, 191 (1961). Municipal immunity under $\S 1983$ is to be distinguished from the prevailing view that persons not otherwise immunized by $\S 1983$ nevertheless will not be liable for the constitutional torts of their servants under the doctrine of respondeat superior. Sebastian v. United States, 531 F.2d 900, 904 (8th Cir.), cert. denied, 97 S. Ct. 153 (1976); Milton v. Nelson, 527 F.2d 1158, 1159 (9th Cir. 1975); Jennings v. Davis, 476 F.2d 1271, 1274-75 (8th Cir. 1973). Contra, Croy v. Skinner, 410 F. Supp. 117, 123-24 (N.D. Ga. 1976); Hill v. Toll, 320 F. Supp. 185, 188-89 (E.D. Pa. 1970); C. Antieau, Federal Civil Rights Act: Civil Practice $\S 90$ at 117 (1971). Of course, Aldinger might have argued alternatively that this rule should not apply, or, even if it did as a matter of federal law, it did not confine the scope of vicarious liability under state law. Finally, this rule does not preclude claims of independent personal liability, although the combined effect of Monroe's municipal immunity and Aldinger is to preclude federal suits against municipalities whether the theory of recovery is personal or vicarious liability.

${ }^{66} 412$ U.S. 507 (1973). See Kates \& Kouba, supra note 46, at 147-52.

${ }^{67} 411$ U.S. 693 (1973). See note 81 infra.

${ }^{68}$ See note 81 infra \& text accompanying notes 91-94 infra.

${ }^{69}$ See, e.g., Bishin, The Law Finders, An Essay in Statutory Interpretation, 38 S. CaL. L. REv. 1, 3 (1965). See generally Frankfurter, Some Reflections on the Reading of Statutes, 47 Colum. L. Rev. 527, 540-44 (1947).

7096 S. Ct. at 2421-22 n.12. 
standing in 1871 of the Sherman Amendment proposal must be examined in addition to Monroe in order to determine what was the intended scope of the municipality exemption. Because Aldinger's inference of congressional intent to bar local governments as pendent parties to section 1983 actions depends solely on the holding in Monroe and its progeny that local governments are immune from federal liability under section 1983-a holding that in turn depended solely on the legislative history of the provision-the legislative history itself must be evaluated to understand the limits of the exemption perceived by Monroe. This understanding is relevant to the assumption underlying $\mathrm{Al}$ dinger's circumvention rationale - that the intent to exclude municipalities from federal liability disfavors pendent party jurisdiction over municipalities altogether. ${ }^{71}$

Although the congressional debates on the Sherman Amendment confirm the observation in Monroe, followed in Aldinger, that the House of Representatives overwhelmingly rejected the imposition of federal liability on municipalities, ${ }^{72}$ they also reveal the accuracy of two points made by Mr. Justice Brennan, dissenting in Aldinger: first, that the House responsible for rejecting the Sherman Amendment was aware of several state laws waiving vicarious municipal immunity in tort for damage incurred from riots within the municipality; second, that the debates evidence hostility only to imposing liability under federal law, not to conferring federal jurisdiction over state-created claims against cities and counties. ${ }^{73}$

Because the House was aware that, at least in four states, the local government was already vicariously liable under state law for the same acts that would have been actionable under the Sherman Amendment, ${ }^{74}$ it might have felt unjustified in imposing additional federal liability. In rejecting the Sherman Amendment, the Congress explicitly recognized that the very liability they refused to impose on the federal level did in fact exist on the state level.

${ }^{71} \mathrm{Mr}$. Justice Brennan, in dissent, challenged the majority to explore the legislative history of $\S 1983$. He concluded that the intent of the $42 \mathrm{~d}$ Congress was to avoid imposing federal liability for civil rights incursions on local governments, not to bar their presence in federal court altogether. $I d$. at 2424-30. The Court responded that the debates cited indicate, if anything, only that the enactment of the 1871 Act was not meant to alter federal diversity jurisdiction of municipal corporations. Id.

${ }^{72}$ Cong. Globe, 42d Cong., 1st Sess. 804 (1871) (remarks of Rep. Poland).

7396 S. Ct. at 2425 (Brennan, J., dissenting).

${ }^{74}$ The Sherman Amendment was very similar to, and probably modelled on, some of these state provisions. Compare Cong. Globe, 42d Cong., 1st Sess. 663 (Sherman Amendment) with id. 792 (Massachusetts law). 
An examination of the legislative history of section 1983, even acknowledging the opposition to imposing federal liability on local governments, nonetheless recognizes that such liability could rightfully exist under state law. Although section 1983 does not reach municipalities whose immunity is waived by state law, ${ }^{75}$ such a waiver may impose vicarious liability on the municipality as a matter of state law, consistent with the congressional intent in enacting section 1983. This is precisely what Aldinger attempted: to recover from the county's agent under federal law and from the county under state law of respondeat superior and waiver of municipal tort immunity. ${ }^{76}$

Justice Brennan's second point is that the legislative history bespeaks no hostility to litigating state claims against local governments where authorized by an independent state grant of subject matter jurisdiction. ${ }^{77}$ In its blanket holding that section 1983 will not support a pendent party action, Aldinger focused exclusively on the scope of the federal claim and its exemption of municipalities, ignoring the relationship of the proposed pendent claim. This approach is not warranted by the legislative history. Even if joinder of a state claim of respondeat superior contingent on the underlying section 1983 liability and on nothing more is an impermissible "circumvention" of the local government exemption under section 1983, the legislative history does not warrant denying pendent party jurisdiction against the city or county where the state claim arises independently under state law within the same operative facts. Easily imaginable cases, ${ }^{78}$ such as a state claim for breach of a municipal employment contract pendent to a section 1983 claim for unconstitutional dismissal, would meet Mr. Justice Brennan's observation that

${ }^{75}$ Moor v. County of Alameda, 411 U.S. 693, 698-710 (1973). The contrary view had been espoused in Carter v. Carlson, 447 F.2d 358 (D.C. Cir. 1971), rev'd on other grounds sub nom. District of Columbia v. Carter, 407 U.S. 418 (1973). Other circuits, by contrast, reached the same result later approved by the Court in Moor. E.g., Ries v. Lynskey, 452 F.2d 172 (7th Cir. 1971); Brown v. Town of Caliente, 392 F.2d 546 (9th Cir. 1968). Cf. Greenway v. Thompson, 368 F. Supp. 387 (N.D. Ga. 1973) (city may not be pendent party defendant to $\$ 1983$ action when state has not waived municipal immunity for torts of government employees).

${ }^{76}$ See note 5 supra.

7 E.g., Cong. Globe, 42d Cong., 1st Sess. 794 (1871) (remarks of Rep. Poland).

${ }^{78}$ Such cases have already arisen. E.g., Stamm v. Trigg, 368 F. Supp. 83 (N.D. Ohio 1973) (claim of negligence against prison doctors pendent to $\S 1983$ claim against prison authorities); Anthony v. Cleveland, 355 F. Supp. 789, 793 (D. Hawaii 1973) (breach of contract pendent to $\$ 1983$ claim against state university). Stamm retained jurisdiction; Anthony, following the Ninth Circuit rule, dismissed the pendent claim. See note 21 supra. 
Congress did not wish to disturb independent jurisdiction of state law claims against cities. ${ }^{79}$

\section{The Significance of Alternative Theories of MUNiCIPAL LIABILITy}

In addition to resting on questionable historical assumptions, the Court's concern about "circumvention" of the local government exemption under section 1983 fails to consider related provisions ${ }^{80}$ that may authorize a similar result, such as federal question jurisdiction.

A claim not made in Aldinger arises when civil rights plaintiffs rely on general federal question jurisdiction, ${ }^{81}$ alleging the requisite amount in controversy and seeking relief directly under the appropriate constitutional guarantee ${ }^{82}$ instead of under section 1983 and the civil rights jurisdictional grant. ${ }^{83}$

${ }^{79}$ As federal question jurisdiction was not enacted until 1875 , Congress only intended that diversity suits against municipalities, premised on state law, not be disturbed.

${ }^{80}$ One such related provision is 42 U.S.C. $\$ 1988$ (1970), stating that where federal laws "are not adapted to the object [of protecting the civil rights of all persons in the United States], or are deficient in the provisions necessary to furnish suitable remedies ...," state laws, "not inconsistent with the Constitutional and laws of the United States," may be used as a supplement to remedy the deficiency. This wording is susceptible to ambiguous application in the Aldinger context. On the one hand, the provision's concern about suitable remedies might suggest the use of state liability where necessary to make $\S 1983$ "fully effective." On the other hand, the desire for consistency appears to foreclose $\S 1988$ liability because the importation of state waiver of municipal immunity might be viewed as contrary to the congressional intent to exclude government entities from liability under $\S 1983$. Moor v. County of Alameda, 411 U.S. 693 (1973), exploring the limits of $\$ 1988$ in relation to section 1983 , chose the latter interpretation. $I d$. at 698-710. In Moor, the Court upheld the dismissal of a $\$ 1988$ action against a municipality on the grounds that such a suit would thwart Congress' intent in $\S 1983$.

Yet Moor does not govern the outcome in Aldinger. A commentator recently suggested that Moor's holding "rests not upon an extension of Monroe's rule that section 1983 does not reach municipalities, but upon the limited function of $\S 1988$ in the scheme of federal civil rights legislation." "Note, Damage Remedies Against Municipalities for Constitutional Violations, 89 HaRv. L. Rev. 922, 941 (1976) (quoting 411 U.S. at 700 n.10). Moor was concerned that $\S 1988$ not be seen as authorizing the "wholesale importation into federal law of state causes of action." 411 U.S. at 703-04. Aldinger's suit, by contrast, involved no such danger. She did not seek an extension of federal liability but only the opportunity to litigate a state claim in federal court. Moor's holding does little, therefore, to support Aldinger's circumvention rationale. Mr. Justice Brennan concurred in Moor's finding that $\S 1988$ could not be used to supply a right against municipalities as a matter of federal law, but dissented from Aldinger's finding that raising the state claim in federal court impermissibly circumvents the limitations on $\S 1983$.

8128 U.S.C. $\$ 1331$ (1970).

${ }^{82}$ E.g., Bivens v. Six Unknown Named Agents, 403 U.S. 388 (1971) (fourth amendment).

${ }^{83} 28$ U.S.C. $\S 1343(3)(1970)$. 
Whether federal question suits may be maintained against parties immune from liability under section 1983 is unclear. The curious result of permitting such actions would be to hold municipalities answerable for incursions on constitutional rights only when the court valued such rights above the jurisdictional minimum so as to qualify for federal question jurisdiction. That courts have taken divergent attitudes in valuating the amount in controversy in cases premised solely on the abridgment of such intangibles as constitutional rights indicates the uncertainties of this approach. ${ }^{84}$ Nevertheless, articulate justifications for such results have been made, ${ }^{85}$ and federal question suits premised directly on the Constitution have attained results even beyond the reach of a parallel section 1983 action. ${ }^{86}$

${ }^{84}$ Compare Grant v. Hogan, 505 F.2d 1220, 1225 (3d Cir. 1974) (amount in controversy must be met to sustain $\S 1331$ jurisdiction in civil rights suit) with Rowland $v$. Tarr, 378 F. Supp. 766, 770 (E.D. Pa. 1974) (court will accept plaintiff's representation that two years in military is worth over $\$ 10,000$ to him).

${ }^{85}$ Examination of the legislative histories of $\S \S 1983$ and 1331 suggests that the bar against suing a municipality under $\S 1983$ should not be read into $\$ 1331$. The legislative history of $\S 1983$ reviewed by the Court in Monroe shows that the absence of a required amount in controversy was one of the concerns voiced by the Act's opponents. ... When the predecessor of $\S 1331$ was passed four years later, however, it included the requirement of a stated amount in controversy. The passage of $\S 1331$ was also motivated by very different considerations than those to which $\S 1983$ was a response. $\S 1983$ was an effort by the Congress to provide a forum and a remedy for those whose rights were being violated but who could get no relief in the courts or agencies of their states. . . Amendments were offered extending liability specifically to include cities and counties, but many members of Congress were unwilling to extend liabilities to municipalities, "the mere instrumentality for the administration of state law.' . . As finally passed, the act provided redress only against the persons who were depriving others of their rights. The Act of March 3, 1875, the predecessor of $\S 1331$, on the other hand, was the culmination of efforts dating back to the first Congress to give general federal question jurisdiction to the federal judiciary. See Chadbourn \& Levin, Original Jurisdiction of Federal Questions, 90 U.Pa.L. Rev. 639, 639-645 (1942). This revolutionary step in strengthening the federal government against the states was made with no substantive debate ... The record is silent as to whether Congress meant to make municipalities liable for the acts of their agents which violate federal law. While it may be argued that Congress assumed that suits in federal court against municipalities would be unconstitutional, as had recently been vigorously argued in the debates over the passage of $\$ 1983 \ldots$, it is not the role of the Court to read in such a limitation in the absence of any legislative history. Dahl v. City of Palo Alto, 312 F. Supp. 647, 650-51 (N.D. Cal. 1974), quoted with approzial in Sixth Camden Corp. v. Township of Evesham, 420 F. Supp. 709, 716-17 (D.N. J. 1976). For a detailed analysis reaching the same conclusion, see Note, supra note 81 , at $939-51$.

${ }^{86}$ City of Kenosha v. Bruno, 412 U.S. 507, 516 (1973) (Brennan, J., concurring); District of Columbia v. Carter, 409 U.S. 418, 432-33 (1973) (federal question jurisdiction supports civil rights suit against District police immune under $\S 1983$ because District law is not "state" law within meaning of $\S 1983$ ) (dictum); Hampton v. Holmesburg Prison Officials, 546 F.2d 1077 (3d Cir. 1976); Cox v. Stanton, 529 F.2d 47 (4th Cir. 
Aldinger's effect on this trend is significant. Two recent district court opinions cited it for the proposition that municipalities may not be sued under the fourteenth amendment because of the analogous section 1983 exemption and the circumvention rationale. ${ }^{87}$ This incipient reading of Aldinger would inadvertently render the Court's guarded holding a fundamental revision or the meaning of federal question jurisdiction-a change so important the Supreme Court declined to decide it in both City of Kenosha v. Bruno ${ }^{88}$ and Aldinger. ${ }^{89}$ The influence of Aldinger on constitutional federal question claims against municipalities awaits clarification by the Court, but the potency of the circumvention rationale is increasingly obvious.

The Court's single-minded focus on the scope of section 1983 to determine the limits of pendent party jurisdiction is difficult to harmonize with the possibility of imposing liability on municipalities directly under the federal constitution. By adopting the Gibbs focus on the character of the pendent claim, the Court might have weighed the cautionary value of Congress' municipality exemption under section 1983 against countervailing factors and plausible expressions of congressional intent in favor of municipality liability. Even if the federal question jurisdictional grant does not specifically refer to municipalities, other enactments imposing federal liability on municipalities for fourteenth amendment violations suggest that there is no modern congressional policy absolutely exempting municipalities from such responsibility. ${ }^{90}$ Additionally, the Forty-Second Congress

1975); Skehan v. Board of Trustees of Bloomsburg State College, 501 F.2d 31, 44 (3d Cir. 1974), vacated $छ$ remanded on other grounds, 421 U.S. 983 (1975); Hartigh v. Latin, 485 F.2d 1068 (D.C. Cir. 1973), cert. denied, 415 U.S. 948 (1974); Gomez v. Wilson, 477 F.2d 411, 419-21 \& n.56 (D.C. Cir. 1973). See Patterson v. Ramsey, 413 F. Supp. 523, 528 (D. Md. 1976) (collecting district court cases). But see Nguyen Da Yen v. Kissinger, 528 F.2d 1194, 1200-01 \& n.10 (9th Cir. 1975) (withholding judgment on federal question claims against parties immune under $\$ 1983$ ); Apton v. Wilson, 506 F.2d 83, 95-96 (D.C. Cir. 1974) (same). In Brault v. Town of Milton, 527 F.2d 730 (2d Cir. 1975), a panel of the Court of Appeals, in deciding to grant appellee's application for a rehearing of an appeal en banc, ruled that $\$ 1331$ would support a suit against parties not reachable under $\S 1983$. The Second Circuit upon rehearing en banc declined to decide the 14th amendment question and the other issues raised by the parties, including the $\$ 133$ I question. Id. at 736 .

${ }^{87}$ Dawes v. Philadelphia Gas Comm'n, 421 F. Supp. 806, 821 (E.D. Pa. 1976); Pitrone v. Mercadante, 420 F. Supp. 1384, 1390-91 (E.D. Pa. 1976). But see Hupart v. Board of Higher Educ., 420 F. Supp. 1087, 1103-04 (S.D.N.Y. 1976) (\$1331 supports claim against defendant not joinable as pendent party on authority of Aldinger).

${ }^{88} 412$ U.S. 507, 514 (1973) (refusing to decide issue without adequate briefing).

$8996 \mathrm{~S}$. Ct. at 2415-16 n.3.

90 E.g., 42 U.S.C. $\S 2000 \mathrm{e}(\mathrm{a}),(\mathrm{b})$, \& (h) (Supp. IV 1974) (employment discrimination). 
remitted municipalities from liability for reasons that have largely dissipated in the intervening years. ${ }^{91}$

Aldinger inferred the exemption on the basis of the rejection of the Sherman Amendment-a provision imposing a much harsher result than most applications of respondeat superior by way of pendent party jurisdiction. ${ }^{92}$ Finally, to permit pendent party or federal question actions against municipalities would counter the criticism that the municipality exemption defeats the broadly remedial purposes of section 1983 by frequently precluding suits against a financially responsible defendant, ${ }^{93}$ without altering the scope of section 1983 to achieve this goal.

\section{Problems with the Circumvention Rationale}

The issue in Aldinger was not whether the county defendant must answer for plaintiff's alleged injury but rather whether it

91 This argument is made in McCormack, supra note 17, at 28-30; Note, supra note 81 , at $947 \&$ n.133. The reasons for Congress' conclusion that it lacked constitutional power to impose liabilities were never clearly articulated by the $42 \mathrm{~d}$ Congress. Possible grounds are the 10th amendment, see Cong. Globe, 42d Cong., lst Sess. 788 (1871) (remarks of Rep. Kerr), the 11 th amendment, and the absence of a "state action" requirement, see id. 772 (remarks of Sen. Thurman). The accuracy of Gongress' own view of its power in this respect is doubted by Justice Douglas, dissenting in City of Kenosha v. Bruno, 412 U.S. 507,520 (1973), and somewhat more reservedly by the Court in Moor v. County of Alameda, 411 U.S. 693, 709 (1973). The 1 It th amendment does not bar suits against municipalities, e.g., Markham v. City of Newport News, 292 F.2d 711 , 716-18 (4th Cir. 1961); see Illinois v. City of Milwaukee, 406 U.S. 91, 98-101 (1972); the absence of a state action requirement in the Sherman Amendment would be irrelevant to attempts to join a municipality as a pendent party defendant to a claim of unconstitutional action by its agent. See note 93 infra.

A more pragmatic reason for the exemption was the fear of draining local treasuries to compensate individuals for the depredations of the Ku Klux Klan. Cong. GlobE, 42d Cong., 1st Sess. 763-64 (1871) (remarks of Sen. Casserly). The widespread waiver of governmental immunity by the states themselves for the torts of their employees, and the proposed liability for private action in the Sherman Amendment, see note 93 infra, suggest a lesser concern for local treasuries. See kates \& liouba, supra note 46, at 136-37; McCormack, supra note 17, at 28-30.

${ }_{92}$ The Sherman Amendment, supra note 62 , was harsh but aimed only at a particular evil. It would have required the political subdivision to relieve the effects of riot within its borders at suit of the damaged individual even where the municipality had neither the duty nor the means of keeping peace nor awareness or control of the private wrongdoer. The drastic nature of this strict liability met strong opposition. E.g., CoNg. Globe, 42d Cong., 1st Sess. 762 (1871) (remarks of Sen. Stevenson); id. 776-77 (Sen. Freilinghausen); id. 787-88 (Rep. Kerr); id. 763-64 (Sen. Casserly). As one student commentator has observed, "[T] he evil against which the Sherman Amendment" was directed and the liability which it proposed bear little resemblance to those associated with a [federal question damage suit premised on the Fourteenth Amendment] against municipalities ...." Note, supra note 81 , at 948 . The same might be said of Aldinger's respondeat superior claim against the pendent county defendant.

${ }^{93}$ See Kates \& Kouba, supra note 46, at 136-37 (citing authorities); McCormack, supra note 17 , at $28-30$. 
need do so in federal or state court. The Court's circumvention rationale is persuasive only where the state claim is so similar to the federal claim that the defendant would unjustly be subjected to a judgment under state law while the parallel federal law would absolve him in the same suit. The rationale has considerably less force where the pendent claim arises from the same facts but on a different legal theory than the federal claim. ${ }^{94}$ But under Aldinger a state claim arising from the same operative facts as a federal claim but reaching additional parties, thereby implicating federal policy and presenting a propitious case for the exercise of pendent jurisdiction under Gibbs, is likely to be dismissed because it appears to extend federal liability, and not just federal jurisdiction, to parties "excluded" by Congress. The plaintiff is thus in a double bind: to avoid Aldinger, he must demonstrate that his pendent party claim is sufficiently independent from the federal one so that the exemption of the pendent defendant from federal liability does not imply a congressional intent to shield that party from state-created liability in federal court. ${ }^{95}$ But requiring the claims to be sufficiently independent undermines the very argument in $G_{i b b}{ }^{96}$ favoring pendent party jurisdiction: where the pendent claim clearly implicates federal policy, or where the facts to be proven on both claims are essentially similar, then discretion to hear the state claim is properly exercised.

Aldinger's approach in contexts besides section 1983 will produce illogical results, as one example outside the civil rights area indicates. In Connecticut General Life Insurance Co. v. Craton, ${ }^{97}$ a labor union sued an employer and insurance company for a

${ }^{94}$ See text accompanying note 79 supra.

${ }^{95} \mathrm{~A}$ case in which the state claim adds vicarious liability to an underlying federal liability, and the only additional facts to be proven concern the agency relationship of the state and federal defendant, presents a more workable opportunity for joinder than does a case in which an independent state theory of liability requires proof of many additional facts. See Kates \& Kouba, supra note 46, at 166-67. Aldinger, however, counsels that the former case more likely represents a "circumvention" of limits on federal liability, requiring dismissal of the pendent party claim.

96 "There may . . . be situations in which the state claim is so closely tied to questions of federal policy that the argument for exercise of pendent jurisdiction is particularly strong." United Mine Workers v. Gibbs, 383 U.S. 715, 727 (1966). In Gibbs, the pendent state contract claim was answered on the theory that the federal labor statutes (which gave rise to the jurisdiction-conferring federal questions in the case) had preempted the field. The Court said, "In the present case . . . the allowable scope of the state claim implicates the federal doctrine of pre-emption; while this interrelationship does not create statutory federal question jurisdiction .... its existence is relevant to the exercise of discretion." Id. (citations omitted). See generally Kates \& Kouba, supra note 46 , at 167 .

${ }^{97} 405$ F.2d 41 (5th Cir. 1968). 
declaration of rights accruing to the union members under a health insurance plan contracted between the two defendants pursuant to a collective bargaining agreement between the plaintiff union and defendant employer. Section 301 of the Labor Management Relations Act ${ }^{98}$ conferred subject matter jurisdiction over the action between the parties to the collective bargaining agreement. The Fifth Circuit held that, even if a suit against the defendant insurance company was not within the jurisdictional ambit of section 301 , the district court properly heard the contract claim under the doctrine of pendent party jurisdiction: "[T] he fact that the claims under the insurance contract and the collective bargaining agreement originated in a 'common nucleus of operative fact' gave the district court pendent jurisdiction over Connecticut General irrespective of the dimensions of $\S 301 . " 99$

The court acknowledged several considerations favoring pendent jurisdiction: the plaintiff would otherwise have had to split alternative claims, creating the possibility of inconsistent results; ${ }^{100}$ although the contract claim arose under state law, it implicated federal labor policy; and, as the court observed, the procedural posture of the case counseled against discretionary dismissal of the pendent claim. ${ }^{101}$ A mechanical application of Aldinger, however, would probably require dismissal, in that the court allowed joinder of the federal and pendent claims without referring to "the dimensions of $\S 301$ "-a provision that would not reach the defendant.

The circumvention rationale presents a second difficulty. Aldinger should be limited to instances where the exemption is from substantive liability rather than from the failure to meet a jurisdictional prerequisite. In the latter situation, Gibbs would warrant the joining of claims out of fairness to the plaintiff. Mr. Justice Rehnquist attempted to distinguish Gibbs on the ground that Aldinger, unlike Gibbs, was complicated by the presence of a congressional grant of jurisdiction narrowing the bounds of the federal action. ${ }^{102}$ Because of this exclusion of municipalities from substantive federal liability, he inferred that section $1343(3)^{103}$ of title 28 , which grants civil rights jurisdiction over

9829 U.S.C. $\$ 185$ (1970).

${ }^{99} 405$ F.2d at 48 (emphasis supplied).

${ }^{1011}$ The union alleged that either the insurance company was not fulfilling the contract or that the employer had failed to abide by the collective bargaining agreement. Id. at 43 .

101 Id. at 48 .

$10296 \mathrm{~S}$. Ct. at 2420-21.

10328 U.S.C. \& 1343(3) (1970). 
"any civil action authorized by law," could not confer jurisdiction in a federal civil rights suit over a pendent municipality defendant. ${ }^{104}$ By collapsing questions of jurisdiction and substantive liability, the Court does not acknowledge that its circumvention rationale should apply only when the challenged pendent party is exempt from liability under substantive federal law, and not when the exemption is purely jurisdictional, as when the pendent party fails the rule of complete diversity or is defendant to a federal claim below the jurisdictional minimum. ${ }^{105}$ As $\mathrm{Mr}$. Justice Brennan observed:

At one level of analysis, this test is of course meaningless, being capable of application to all cases, because all instances of asserted pendent party jurisdiction will by definition involve a party as to whom Congress has impliedly "addressed itself" by not expressly conferring subject-matter jurisdiction on the federal courts. ${ }^{106}$

The distinction between a claim that fails to meet federal jurisdictional prerequisites, and a claim that fails because the defendant is immune under substantive federal law is illustrated by Almenares $1 . W_{y} m a n .^{107}$ The Second Circuit approved pendent party jurisdiction of a class action litigating aspects of the federal AFDC statute ${ }^{108}$ although the class failed to satisfy the amount in controversy prerequisite to federal question jurisdiction. As in Aldinger, the jurisdictional anchor was a section 1983 claim against different defendants than those in the class action. A literal application of Aldinger forecloses pendent party jurisdiction in section 1983 suits generally. Yet in Almenares, the scope of section 1983 is patently irrelevant to the court's power to hear the class action, which arises on a legal theory independent of section 1983 and fails to trigger federal jurisdiction not because the defendants are immune under section 1983 but because the amount in controversy is wanting. Aldinger would automatically require dismissal of the pendent party claim because jurisdiction rested on section 1983. Yet the advantages of construing federal welfare law in federal court, and thus incidentally avoiding the constitutional questions broached by the underlying civil rights claim, ${ }^{109}$ are undeniable.

${ }^{104} 96 \mathrm{~S}$. Ct. at 2421.

${ }^{105}$ See cases cited in note 23 supra.

$10696 \mathrm{~S}$. Ct. at 2424 (Brennan, J., dissenting) (emphasis in original).

111453 F.2d 1075 (2d Cir. 1971), cert. denied, 405 U.S. 944 (1972).

110842 U.S.C. $\$ \$ 601-610$ (1970).

${ }^{\text {tim }}$ See text accompanying note 30 supra. 


\section{ConClusion}

Aldinger demonstrates that the path to a comprehensive law of pendent party jurisdiction is unfinished. As the Court limited its holding to a per se ban on the joining of nonfederal parties only to section 1983 actions, ${ }^{110}$ cases arising under other grants of federal jurisdiction presumably will continue to be decided under the Gibbs rule. ${ }^{111}$ To these cases, Aldinger only admonishes that limitations inhering in the jurisdiction-conferring statute may imply a congressional intent to so shape the contours of the pendent action.

The problems inherent in Aldinger argue especially strongly against extending its line of analysis. The circumvention rationale has little meaning where the pendent claim joined to a section 1983 action is in no sense contingent on a finding of federal liability. ${ }^{112}$ The Aldinger approach has no application to situations in which the pendent party defendant can only demonstrate that the claim against him is not cognizable under federal subject matter jurisdiction. ${ }^{113}$

Aldinger's rigidity and potential broadness are difficult to justify logically, and may lead to disallowance of pendent actions that should be heard in federal court. ${ }^{14}$ Section 1983 litigants will now face substantial strategic problems. ${ }^{115}$ They must either bring a federal court action against the employee and a state court action of respondeat superior, with attendant res judicata problems, or argue the entire cause in state court. If Aldinger is applied in other contexts, it may lead to similar problems.

110 The Court eschewed an "all-encompassing jurisdictional rule," $96 \mathrm{~S}$. Ct. at 2419 , and noted, "We decide here only the issue of so-called 'pendent party' jurisdiction with respect to a claim brought under $\S 1343(3)$ and $\S 1983$. Other statutory grants [of jurisdiction] and other alignments of parties and claims might call for a different result." Id. at 2422.

${ }^{111}$ See text accompanying note 21 supra.

112 Text accompanying notes 78-79 supra.

${ }^{113} \mathrm{Mr}$. Justice Brennan called such an application "meaningless." Text accompanying note 107 supra. See Fawvor v. Texaco, Inc., 546 F.2d 636 (5th Cir. 1977) (on authority of Aldinger, dismissing claim asserted by plaintiff against third party defendant in diversity suit, where plaintiff and third party were not diverse).

${ }_{114}$ Text accompanying notes $96-97$ supra.

115 Aldinger has been held to require dismissal of pendent party claims even where a suit is not brought under 28 U.S.C. \$ 1343(3) and 42 U.S.C. \$ 1983 (1970). Tomkins v. Public Serv. Elec. \& Gas Co., 422 F. Supp. 553 (D.N.J. 1976); Gates v. Brockway Gas Co., 79 CCH Lab. Cas. I 11,780 (C.D. Cal. Aug. 24, 1976). But see Bowen v. Evanuk, 423 F. Supp. 1341 (D.R.I. 1976) (Aldinger held not controlling pendent party claim in diversity suit). 